\title{
SCLEROSING STROMAL TUMOR OF THE OVARY
}

\author{
Berna DILBAZ, Yasemin TASCI, Nuray ULULAR, Omer Faruk DEMIR, Umit GOKTOLGA
}

Ministry of Health, Etlik Zübeyde Hanim Womens Health Research Hospital, Ankara, Turkey

\begin{abstract}
SUMMARY
Sclerosing stromal tumor of the ovary (SST) is a rare neoplasm of the sex cord stromal category which occurs predominantly in the second and third decades of life. Histologically, these tumors are characterized by the pseudolobular pattern of the cellular and hypocellular areas, prominent vasculature and cellular heterogeneity.

We report a case of a unilateral SST of the ovary in a 14-year-old girl with irregular menstruation and dysmenorrhea and describe the clinical, radiologic and histologic findings with reference to other reported cases.
\end{abstract}

Key words: adolescent, ovary, sclerosing stromal tumor

Journal of Turkish Society of Obstetrics and Gynecology, (J Turk Soc Obstet Gynecol), 2011; Vol: 8 Issue: 4 Pages: 286- 8

\section{OVERIN SKLEROZAN STROMAL TÜMÖRÜ}

\section{ÖZET}

Overin sklerozan stromal tümörü, over tümörleri içinde oldukça nadir görülen benign karakterli bir tümördür. Histopatolojik olarak fokal skleroz alanları içeren ödematöz stromanın oluşturduğu pseudolobüler görünüm, heterojen hücre alanları ve belirgin vaskülarizasyon ile karakterizedir. Bu çalışmada, menometroraji ve dismenore ile başvuran 14 yaşındaki adolesan kizda tespit edilen unilateral ovarian sklerozan tümör olgusuna ait ultrasonografi, operasyon ve histopatoloji verileri sunuldu.

Anahtar kelimeler: adolesan, over, sklerozan stromal tümör

Türk Jinekoloji ve Obstetrik Derneği Dergisi, (J Turk Soc Obstet Gynecol), 2011; Cilt: 8 Sayl: 4 Sayfa: 286- 8

\section{INTRODUCTION}

Sclerosing stromal tumor of the ovary (SST) is a very rare subtype of ovarian neoplasm of the sex cord stromal category. This tumor was first described by Chalvaridjian and Scully in 1973(1). Most of the reported cases have been unilateral and all of them are benign. The tumor occurs frequently in the second and third decades of life and most patients present with menstrual irregularity related to an adnexal mass. It is rarely hormonally active and may lead to symptoms of excess androgen ${ }^{(2)}$. The diagnosis of SST is often made by postoperative histopathological examination but differential diagnosis of the other sex cord stromal tumors like fibroma, thecoma and lipoid cell tumors should be considered. In the literature no recurrence after conservative surgery of SST was stated.

\section{CASE REPORT}

In physical examination of the 14-year-old girl applied to our hospital's adolescent gynecology clinic with the complaints of menometrorrhagia, dysmenorrhea and

Address for Correspondence: Yasemin Taşçı. Ankara Etlik Doğumevi 06010, Ankara

Phone: + 90 (312) 3220180

e-mail: yytasci@yahoo.com

Received: 06 July 2010, revised: 06 July 2010, accepted: 08 December 2010, online publication: 30 December 2010 
pelvic pain starting five months earlier, a solid mass of 6-7 $\mathrm{cm}$ diameter was palpated in the right hypogastric area. In abdominal ultrasonography a heterogeneous predominantly solid mass of 80 x $47 \mathrm{~mm}$ dimension with some cystic foci was found in right ovary. The mass contains quite a lot number of vessels with peripheral location and with low resistance flow in color Doppler sonography.

All laboratory tests including tumor markers and serum hormonal assays were found to be normal. At laparoscopy a yellow, multilobulated and wellcircumscribed solid ovoid mass arising from right ovary was seen. Left ovary and other pelvic surfaces were normal; no abdominal free fluid was observed. Mass was removed by minilaparotomy and diagnosed as benign by frozen section so operation was terminated. Post-operative recovery was uneventful.

Gross examination showed an encapsulated, solid mass having edematous appearance in cutting surface and containing small cystic areas. Microscopic examination showed typical pseudolobular patterns where cellular areas are separated by edematous and collageneous hypocelluler areas and prominent vascularity. Cellular areas were formed of vacuolated spindle and polygonal cells (Figures 1 and 2).

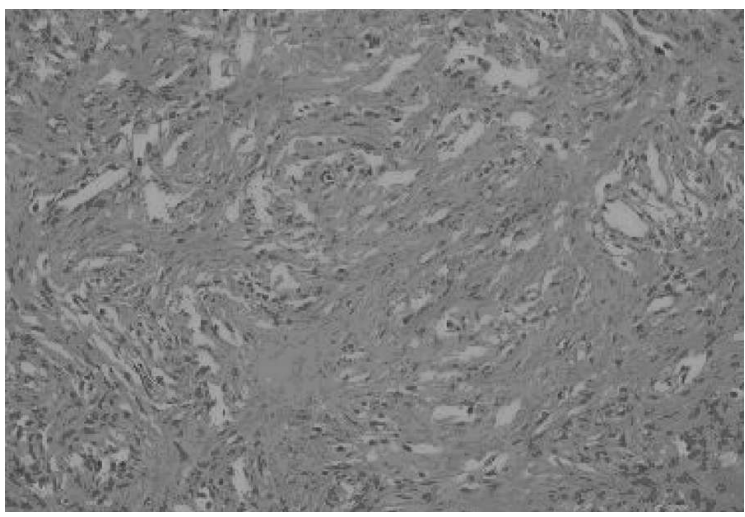

Figure 1: Cellular areas composed of vacuolated spindle and polygonal cells $(x 40)$.

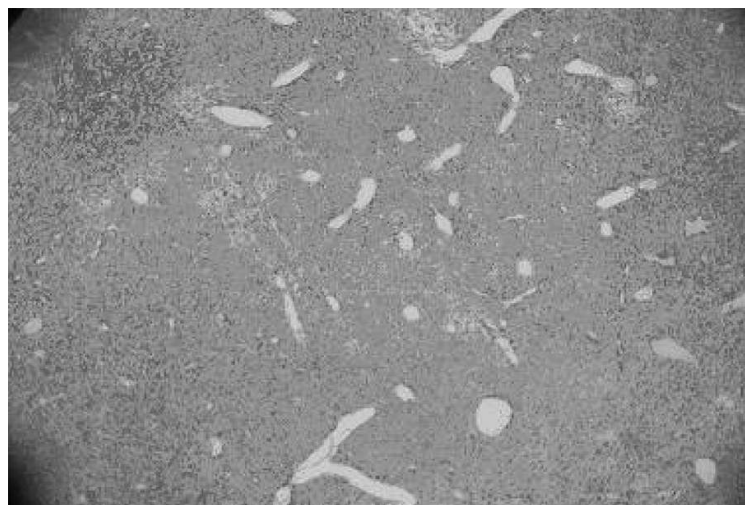

Figure 2: Hypo and hypercellular areas.

\section{DISCUSSION}

Sclerosing stromal tumor of the ovary has distinctive clinical and histopathologic features which differentiates it from other stromal tumors. In the literature the tumor occurs frequently in the second and third decades of life, but in a small number of cases tumor are found in postmenopausal and childhood period ${ }^{(3,4)}$, or in adolescence and premenarchal period ${ }^{(5,6)}$. The usual tumor-specific complaints are pelvic pain and menstrual irregularity although some cases with premature menarche and ascites have been reported. The histologic features is called as hemangiopericytoma-like pattern including a pseudolobular pattern with focal areas of sclerosis, heterogeneous group of cells containing fibroblast-like spindle cells and vacuolated polygonal cells, edematous stroma and prominent vasculature. It has occasionally been confused with thecofibroma and massive ovarian edema. In a report, it was stated that the cellular nodular areas and prominent vascularity in SST and age of cases may help to differentiation from thecofibroma ${ }^{(7)}$. The distinction between SST and massive ovarian edema depends on presence of heterogeneity and preserving of ovarian tissues ${ }^{(7)}$. Immunochemistry stain can be useful in distinguishing SST from Krukenberg's tumor and thecofibroma in suspected cases ${ }^{(8)}$. Mostly, sonographic findings of SST showed solid mass with cystic focus and prominent vascularity as in our study. But it is difficult to differentiate SST from a malignant tumor in imaging studies. In literature the results of studies comparing the effectiveness of sonography, CT and MRI in detection of SST preoperatively are controversial $(6,9)$. According to some authors, the possibility of SST is high in the presence of high density stroma and low density nodules in MRI ${ }^{(6,10)}$. However, there are some studies indicating that other stromal tumors and metastatic ovarian tumors could result in similar MRI findings ${ }^{(9)}$. Ultrasonography and color Doppler examination, though not so specific as MRI or CT, can be correlated to histopathology since it demonstrates the solid, pseudolobular appearance of peripheral tumoral tissue that looks like myometrium in echogenity, the central hypoechoic areas with edematous degeneration and the typical peripheral vascularity around the tumor tissue ${ }^{(6)}$.

In presented case, peripheral tumoral tissue that resembles myometrial echogenity and prominent 
vascular pattern were shown by abdominal sonography; since the tumor markers were within normal ranges, the patient was young and there was the availability intraoperative frozen section, a more conservative approach of laparoscopy and mass excision was preferred. In most of the studies about SST, it was seen that laparotomy and salpingo oophorectomy were applied because of the suspicion of malignancy in imaging studies $(6,7,11,12)$. In literature, all cases were diagnosed as benign except for one patient with low grade malignancy reported in $1990^{(13)}$. Possibility of SST should be kept in mind for young cases presented with menstrual irregularity and pelvic mass. In these cases, frozen section should be performed intraoperatively and if it is benign, conservative surgery should be performed as possible because of the future fertility expectation.

\section{REFERENCES}

1. Chalvardjian A, Scully RE. Sclerosing stromal tumors of the ovary. Cancer 1973; 31: 664- 70.

2. Martinelli G, Govoni E, Pileri S, Grigioni FW, Doglioni C, Pelusi G. Sclerosing stromal tumor of the ovary. A hormonal, histochemical and ultrastructural study. Virchows Archiv A 1983; 402: 155- 61 .

3. Youm HS, Cha DS, Han KH, Park EY, Hyon NN, Chong Y. A case of huge sclerosing stromal tumor of the ovary weighing $10 \mathrm{~kg}$ in a 71-year-old postmenopausal woman. J Gynecol Oncol 2008; 19(4): 270- 4 .
4. He Y, Yang KX, Jiang W, Wang DQ, Li L. Sclerosing stromal tumor of the ovary in a 4-year-old girl with characteristics of an ovarian signet-ring stromal tumor. Pathol Res Pract 2009 Jul 13.

5. Chang YW, Hong SS, Jeen YM, Kim MK, Suh ES. Bilateral sclerosing stromal tumor of the ovary in a premenarchal girl. Pediatr Radiol 2009; 39(7): 731- 4.

6. Torricelli P, Lombardi AC, Boselli F, Rossi G. Sclerosing stromal tumor of the ovary: US, CT, and MRI findings. Abdom Imaging 2002; 27: 588- 91.

7. Bildirici K, Ilgici D, Peker B. Overin sklerozan stromal tümörü (Olgu sunumu). Çukurova Üniversitesi Tıp Fakültesi dergisi 2001; 26(3): 147- 51.

8. Kurt G, Ilhan R, Yavuz E, Tuzlalı S, Iplikçi A. Overin sklerozan stromal tümörleri: altı olgu üzerinde morfolojik ve immünhistokimyasal analiz. Türk Patoloji Dergisi 2004; 20(3-4): 66- 8.

9. Kawamura N, Kamoi I, Shigyo R. Sclerosing stromal tumor of the ovary. Br J Radiol 1987; 60: 1031- 3.

10. Calabrese M, Zandrino F, Giasotto V, Rissone R, Fulcheri E. Sclerosing stromal tumor of the ovary in pregnancy: clinical, ultrasonography, and magnetic resonance imaging findings. Acta Radiol 2004; 45: 189- 92.

11. Iravanloo G, Nozarian Z, Sarrafpour B, Motahhary P. Sclerosing stromal tumor of the ovary. Arch Iranian Med 2008; 11(5): 5612.

12. Chang W, Oiseth SJ, Orentlicher R, Agarwal G, Yahr LJ, Cayten CG. Bilateral sclerosing stromal tumor of the ovaries in a premenarchal girl. Gynecol Oncol 2006; 101: 342- 5.

13. Lopes JM, Seruca R, Hall AP, Branco P, Castedo SM: Cytogenetic study of a sclerosing stromal tumor of the ovary. Cancer Genet Cytogenet 1990; 49: 103- 6. 